\title{
The militarisation of English schools: Troops to Teaching and the implications for Initial Teacher Education and race equality
}

\author{
Charlotte Chadderton, Cass School of Education and Communities, University of East \\ London, c.chadderton@uel.ac.uk
}

\begin{abstract}
This article considers the implications of the Troops to Teaching (TtT) programme, to be introduced in England in autumn 2013, for Initial Teacher Education (ITE) and race equality. TtT will fast-track ex-armed service members to teach in schools, without necessarily the requirement of a university degree. Employing theories of white supremacy, and Althusser's (1971) concept of Ideological and Repressive State Apparatus, I argue that this initiative both stems from, and contributes to, a system of social privilege and oppression in education. Despite appearing to be aimed at all young people, the planned TtT initiative is actually aimed at poor and racially subordinated youth. This is likely to further entrench polarisation in a system which already provides two tier educational provision: $\mathrm{TtT}$ will be a programme for the inner-city disadvantaged, whilst wealthier, whiter schools will mostly continue to get highly qualified teachers. Moreover, TtT contributes to a wider devaluing of current ITE; ITE itself is rendered virtually irrelevant, as it seems TtT teachers will not be subject specialists, rather will be expected to provide military-style discipline, the skills for which they will be expected to bring with them. More sinister, I argue that TtT is part of the wider militarisation of education. This military-industrial-education complex seeks to contain and police young people who are marginalised along lines of race and class, and contributes to a wider move to increase ideological support for foreign wars - both aims ultimately in the service of neoliberal objectives which will feed social inequalities.
\end{abstract}

\section{Keywords}

Militarisation of education; surveillance in schooling; ITE; social inequality; white supremacy

\section{Introduction}

The questions asked when exploring issues of race and ITE in the UK seem to have remained similar over many years: Why does racism persist in the education system? How do teachers continue to end up complicit in racist structures of white supremacy? Is it possible for individual teachers to affect even small changes? How much impact can ITE have on teachers' attitudes? The UK's Coalition government, in power since May 2010, has introduced a range of radical reforms to the education system, which raises questions for the implications for race equality. In this article I consider the implications of the Troops to Teaching (TtT) programme, due to be introduced in England in autumn 2013, in order to reconsider these questions for the present social and political context. TtT would fast-track ex armed-service members to teach in schools, without necessarily the requirement of a university degree to do so (DfE 2012). I argue firstly that this initiative both stems from, and contributes to, a system of social privilege and oppression in education, and contributes to wider policies which devalue current teacher education. Secondly, and possibly somewhat controversially, I argue that the initiative is part of a wider trend to securitise and militarise society in general and education specifically, and should be seen as part of a wider move to remove issues of equality, including racial equality, from the educational agenda.

A consideration of the TtT initiative and the purpose and implications of its introduction offers us fresh insights into the (re)production of structures of white supremacy in the education system. White supremacy in this sense does not solely refer to the actions of 
extreme right-wing groups such as Neo-Nazis or Apartheid, nor only to overt racist systems such as slavery, although it does understand these as extreme forms of structures of discrimination. Rather it refers to social and political structures, which privilege those categorised as white, and disadvantage those categorised as $\mathrm{BME}^{\mathrm{i}}$ (Gillborn 2005; Preston 2007). In an education context, white supremacy is understood as a process which denies BME students and staff the same opportunities as whites, and elevates the position of whites (Diangelo 2006). The term white supremacy, therefore, does not necessarily refer to skin colour, rather to structures of domination and oppression which shape values, attitudes, interpretations, roles, identities, interaction and policy, which are often invisible to those privileged by them, although those they disadvantage tend to be more aware of these structures. This challenges dominant understandings of racism simply as racial discrimination - white supremacy reveals the system of privilege for whites as well as discrimination for BME individuals. It also challenges understandings of racism only as deliberate, individual and overt actions, by showing that racism can also be unwitting. However, scholars who employ notions of white supremacy often urge a caveat, pointing out that

"although race inequity may not be a planned and deliberate goal of education policy neither is it accidental. The patterning of racial advantage and inequity is structured in domination and its continuation represents a form of tacit intentionality on the part of white powerholders and policy-makers." (Gillborn 2005, 485)

This notion of 'tacit intentionality' is particularly important when analysing policy implications, as it helps us understand that even when a policy is not intended to be racist, it can have racist consequences, which policy-makers might have been able to predict had they studied the outcomes of previous policies.

Like all social structures, structures of white supremacy have to be continually reinforced in order to be effective (Preston 2007). We therefore see it as socially produced and reproduced in social, economic, political and discursive spaces. Racial structures do not function in isolation, but intersect with other categories such as class and gender - however, the intersection with other forms of discrimination should not detract from the importance of white supremacy as a key way of thinking which shapes education policy (Bhopal and Preston 2012).

As a researcher categorised as white myself, I am aware of my contradictory position as a white person writing about white supremacy. As we are all complicit in racial structures, I also receive privileges by virtue of being white (for a fuller discussion of the positioning and complicity of the white researcher, see Chadderton 2012a). I aim to avoid both a fetishistic gaze upon the racial other, and attempting the naive and ultimately futile aim of speaking from beyond whiteness. Rather I employ the framework as an analytical tool and from my unavoidable position within whiteness, I hope my efforts to critically problematise and reveal the structures of white supremacy in education go some small way towards dismantling and abolishing whiteness (Levine-Rasky 2002; Ignatiev 1997).

When considering the military and schooling, one might fruitfully refer to the work of Marxist theorist Althusser (1971). Althusser argued that in order to maintain capitalist relations of production, a range of tools are necessary to ensure the compliance of the population. He identifies what he calls Repressive State Apparatuses (RSAs), which include the government, the church, the courts, the army and prisons; and Ideological State Apparatuses (ISAs), which include religious, educational, family, legal, political and communications control. Although represented as neutral, the RSAs provide more overt 
social control, and the ISAs work at a more subconscious level to ensure that the population internalizes the dominant social values and remains compliant. The two types of State Apparatuses are however, not separate, rather they feed into and sustain each other. The TtT initiative combines the RSA the army, and the ISA education. Throughout most of the $20^{\text {th }}$ century, the dominant form of governance was governmentality (Foucault 1991), which relied more on ISAs than RSAs and was characterized by the de-centring of power and promotion of self-regulation. More recently, social theorists (e.g. Butler 2004; Brown 2011) have argued that we are currently undergoing a shift in governance from governmentality towards sovereignty, characterized by more repressive forms of social control and the more overt exercise of state power, exemplified by a growing culture of militarisation. It is in this light that I consider the implications of $\mathrm{TtT}$.

\section{Troops to Teaching: the policy}

Armed Service leavers are to be encouraged to become teachers and mentors in schools in the TtT programme. The initiative is supported both by the current Coalition government of Conservative (politically right of centre) and Liberal Democrat (centre), and the previous Labour (traditionally left of centre) government. Initial details and reasoning are outlined in the Schools White Paper, The Importance of Teaching (DfE 2010), which gives the main purposes for the introduction of this initiative as twofold: firstly, poor standards of achievement in comparison with other industrialised nations, and secondly, a need for increased discipline in schools. One of the main solutions to these issues, the introduction to the White Paper claims, is to 'raise the status of teaching' by improving the quality of teachers by making changes in the way they are trained (Cameron and Clegg 2010,3). The government therefore firmly places their agenda for improvement in the field of teacher training. In 2008 the Centre for Policy Studies, a centre-right think tank, produced a policy paper initially advocating the introduction of the programme in the UK, based on the success of a similar programme in the US (Burkard 2008). As reported by the BBC, a Department for Children, Schools and Families (DCSF) spokesman said at the time: 'We know that professionals with industry experience can make really inspirational teachers and we are always looking to recruit teachers who have skills in other fields' (BBC 2008).

The Department for Education (DfE) emphasises that there will be opportunities for both non-graduate and graduate Armed Service leavers to enter teaching (DfE 2012). This is in contradiction to the government's own stated commitment to increase the academic requirements for teachers (DfE 2010), highlighting the academic suitability and subject expertise of new teachers as being of particular importance. The White Paper also states a commitment from the government to pay the tuition fees of service leavers (DfE 2010,22), at a time when tuition fees in England have been raised to up to $£ 9,000$ p.a. for other home students, a rise of $300 \%$ on the previous year.

The UK is not alone in introducing such programmes of collaboration between the military and schooling, there are other countries which have them too. The Troops to Teachers (T3) programme in the US, for example, retrains ex-soldiers with a minimum of 10 years' experience, and a degree (BBC 2008). The programme has been in place since 1994 and is administered by the US Department of Defense.

The T3 programme in the US has three main explicit purposes. First, it is one of a range of initiatives to help relieve teacher shortages, particularly in high need subject areas such as Maths, Sciences, Special Education and Vocational Education; it aims to provide employment for veterans; and thirdly it aims to recruit teachers in 'high need', low-income, ethnically diverse, urban areas (DANTES 2011; Broe 2008). Financial support and reduced entry requirements are provided in some states to persuade more troops to join the teaching 
profession (Broe 2008), and as stipulated on the T3 website, '[p]articipants who accept the Stipend or Bonus must agree to teach for three years in schools that serve students from lowincome families' (DANTES 2011).

The programme has been referred to as having been an 'outstanding success', with $88 \%$ remaining in the profession three years after they qualified, compared to the usual retention rate for teachers in the US of 50\% after five years (BBC 2008). 2008 figures suggest that approximately 16,000 ex-service personnel have qualified as teachers since T3 was set up in 1994 (ibid). The programme has also been beneficial in bringing in more men and ethnic minorities to the teaching profession (Marnie 2001). T3 teachers have been reported as being more prepared to teach in inner city schools, and teach shortage subjects such as Maths and Science and in areas such as Special Education and Vocational Education (Feistritzer et al. 1998; Marnie 2001; Owings et al. 2005), and more likely to move where demand for teachers is greatest (Feistritzer 2005). Evaluations have suggested the programme provides 'effective teachers' and 'excellent role models', 'who bring unique and valuable life experiences to the classroom' (Feistritzer et al. 1998, 8). It has been reported that over 90\% of school principals have claimed that $\mathrm{T} 3$ teachers keep better discipline than traditional teachers (Owings et al. 2005).

In Germany, there is a tradition of so-called 'Jugendoffiziere' holding project days at secondary schools, and many German local education authorities have official agreements to work more closely with the military, including the military having input on modules in some teacher training programmes (Schulze von Glasser 2012). Since 2010, there has been an increase in military activity in German schools, both in order to attract more support among the population for Germany's foreign wars (ibid.) (generally unpopular in a country whose population is aware of the controversial nature of its military involvement overseas due to its Nazi legacy), but also as a recruitment drive, since compulsory national service was abolished in 2011 (ibid.).

\section{The social context of the $\mathrm{TtT}$ programme}

For all the advances we have made, and are making in education, we still, every year allow thousands more children to join an educational underclass [...] It is from that underclass that gangs draw their recruits, young offenders institutions find their inmates and prisons replenish their cells. These are young people who, whatever the material circumstances which surround them, grow up in the direst poverty - with a poverty of ambition, a poverty of discipline, a poverty of soul. [...] There is an ironclad link between illiteracy, disruption, truancy, exclusion and crime which we need to break. [...] Over the years there has been a slow, and sustained, erosion of legitimate adult authority in this country. It has been subverted by a culture of dutiless rights which empowers the violent young to ignore civilised boundaries which exist to protect the weak and vulnerable. [...]We need more male teachers [...] to provide children who often lack male role models at home - with male authority figures who can display both strength and sensitivity. [...] And specifically in order to ensure that there are many more male role models entering teaching we will be launching our troops to teachers programme later this autumn, so that we can draft gifted individuals from the armed services into the classroom.

(Michael Gove, Secretary of State for Education 2011)

Some might argue that the introduction of the TtT programme is simply a way of getting service-leavers into employment (e.g. BBC 2008). Whilst this is no doubt one of the aims of the initiative, a consideration of communications about $\mathrm{TtT}$ suggest there are much wider aims as well. The quote above suggests that the TtT programme is not a neutral intervention 
aimed at supporting all young people, despite being presented as such. In his speech, Michael Gove claims to identify 'an educational underclass [...] with a poverty of ambition, a poverty of discipline, a poverty of soul', a group which allegedly includes violent gang members, and is often brought up by women without male support. This group, he argues, is a threat to those he refers to as 'the weak and vulnerable', and destined for a life of crime. The solution he sees as 'adult authority', and possible physical intervention, which he views as best provided by 'male role models' and military-style discipline. Thus TtT is aimed at specific social groups in response to a specific social situation, which will be dealt with in a specific way.

Despite Gove's apparent disclaimer, 'whatever the material circumstances which surround them', TtT seems to be aimed at the economically disadvantaged. Indeed, use of terms such as 'underclass', 'poverty' in Gove's speech make explicit reference to disadvantaged groups, as does Burkhard's (2008) report, which refers to '...children from more deprived neighbourhoods' (p.8). As Dermott (2011) writes, many of the characteristics which those advocating the programme identify provide 'authorial shorthand for a collection of socio-economic markers. It does the same work as "class", but without invoking this contentious idea; thereby giving the impression of objective description rather than valueladen categorization' (pp.6-7). The term 'inner-city', for example, whilst not employed by Gove in this speech, is used throughout Burkard's (2008) paper and also by the BBC, to identify the sorts of young people at which the initiative is aimed, as in, 'to bring military style discipline to tough inner city schools' (BBC 2008).

However, the references to economic and social disadvantage are equally not neutral. The literature on TtT refers not just to disadvantaged young people, but to problematic young people. Schools in urban areas tend to be regarded as problematic due to a widespread belief that many of their pupils are both failing academically, and engaged in anti-social behaviour. Equally, the reference to young people being in 'gangs' - both in Gove's speech above, and on the Gemini Forces website (2011), an ex-military recruitment agency - can be seen as a reference to their class background. There is a wide perception that large numbers of young people, particularly young men in disadvantaged urban areas, are members of organised and violent gangs engaged in 'turf wars' and criminal activity, predatory groups which dominate the streets, intimidate other residents and dictate behaviour and interaction in entire neighbourhoods. Indeed, Gove's reference to 'the weak and vulnerable' suggests he is aiming to give the impression that he differentiates between the violent and criminal poor, and the genuinely needy who are threatened by the latter - similar to traditional discourses which differentiate between the perceived deserving and undeserving poor. However, the speech has the effect of equating disadvantage with criminality and violence. Moreover, other literature shows that whilst organised gangs do exist in the UK, they are not as widespread as often perceived, and relations are much more complicated than the good versus evil binary set up by Gove, including functioning as protection for the more vulnerable (e.g. Joseph et al. 2011).

Explicit links are also made with the protests in summer 2011, a week of rioting and protest on the streets of several English cities sparked off by the shooting by police of a young, working class man of dual heritage in London, and their subsequent refusal to provide any explanation for his death to his family members. These references appear particularly on the Gemini Forces website, which states that the TtT programme has been introduced, '[i]n response to the recent riots in England' (Gemini Forces 2011). The protesters were widely viewed as lower class youths, feckless and taking advantage of a situation for their own gain by looting, not because they are poor, but because they are, as Gove would argue, poor 'of discipline and soul'. 
Seen from an Althusserian point of view, this link between the TtT and the discipline of the lower classes makes perfect sense. The dominant ISA is the school, which teaches young people their role in the capitalist social hierarchy. The disadvantaged need to be taught to accept their position as the lowliest workers,

the reproduction of labour power requires not only a reproduction of its skills, but also, at the same time, a reproduction of its submission to the rules of the established order, i.e. a reproduction of submission to the ruling ideology for the workers (Althusser, 1971).

The combination of an RSA with an ISA is likely to make this learning process even more effective.

Secondly, the literature on TtT implicitly targets boys. Although Gove does not explicitly mention which gender the proposal is aimed at, in the policy paper by the Centre for Policy Studies, at one point there is a mention of boys, and girls are mentioned in brackets. As Dermott (2011) points out in her analysis of gender in the programme, the context to the initiative includes hysteria around the educational under-achievement of boys and bad behaviour in the classroom, seen as an issue of masculinity. As exemplified in Gove's speech above, there are indeed many assumptions made about gender in the literature: that low-achieving children lack male role models in their lives; that there is a causal link between the lack of male role models and young people's under-achievement and anti-social behaviour; that a male teacher improves educational attainment; that men themselves provide a masculine authority which allow them to keep better discipline; that ex-service-leavers (of either gender?) will have access to this masculinity. There is, however, little evidence that any of these assumptions are accurate (e.g. Read 2008).

Commentaries on the TtT programme in the UK are virtually silent on the issue of race. Yet race, like social class, is present implicitly in the language employed. Just as terminology such as 'inner-city' and the assumption that youths are members of organised gangs is classed, it is also raced. England's larger cities are racially diverse, and the notion of violent gangs is associated in popular imagination with African-Caribbean youth (Joseph et al. 2011). There is more generally a perceived connection between BME groups, particularly black and Asian, and crime, violence (e.g. Blair 2000), and more recently, terrorism. Equally, the problematising of young people from families with absent fathers can be seen as racially coded. This is because particularly families where the male partner is of African-Caribbean heritage are perceived to be likely to be headed by lone mothers, black males often stigmatised as sexual predators, unable to remain in a relationship and take responsibility for children (Roopnarine 2004). Moreover, the educational context is also raced as there has been much media attention around the under-achievement of certain BME groups (Gillborn 2005) who have also traditionally been considered badly-behaved and challenging (Blair 2000).

In a documentary programme made by the BBC (2011) which reported on what was hailed as the success of the T3 initiative in the US, and a school in Birmingham in the UK which is already employing ex-army as teachers, virtually every young person on screen is of BME heritage. Whilst this passes without explicit mention, the viewer is left with the impression that the initiative does, indeed, target young BME people rather than white young people.

The literature and the film thus implicitly portray the TtT initiative as aimed at young, disadvantaged, BME (often male) young people, who are positioned as being in need of discipline and authority. This therefore reinforces the alleged, essential links between disadvantaged young BME people, and crime, violence, lack of responsibility and under- 
achievement. The introduction of TtT then, seems to be both informed by, and feed, discourses of white supremacy.

\section{The implications for ITE}

There are two main implications of the TtT programme for ITE. Firstly, it devalues current ITE in several ways. The focus on discipline and authority to tackle (perceived) bad behaviour, youth violence and crime seems to imply that current teachers are unable to cope and the behaviour problems can only be dealt with by sending in the troops. Burkhard's (2008) report seems to suggest that it is the macho and violent image of the military which will inspire respect: ' $[\mathrm{w}]$ hether we like it or not, children from more deprived neighbourhoods often respond to raw physical power' (p.8).

Further, commentators have also noted that although the initiative is touted as encouraging a move away from violence, crime and exclusion, rather than aiming to downplay aggression and violence, what $\mathrm{TtT}$ paradoxically seems to aim to do is embrace aggression (e.g. Dermott 2011). There is no mention of notions of democratic and collaborative values, solidarity, social justice, social transformation, active citizenship and emancipation (Gilbert 2011). This equally seems to imply that current ITE is too 'liberal'. The TtT proposal comes in the context of a wider move in England to 'restore adult authority' in schools, in the form of discipline and unquestioning obedience. The government has also recently announced the scrapping of the requirement for teachers to record instances when they use physical force (Gove 2011). As Giroux (1986) argues, speaking for the US, 'the new conservatives have [...] argued that the current crisis in public education is due to the loss of authority' (p. 22). Although Giroux wrote this a quarter of a century ago, its relevance has only increased, in both the US and UK. Far from being educated to become 'transformative intellectuals' (Giroux 1986, 28), preparing young people for life in a participatory democracy and stimulating critical thought and debate, or technical competence and subject knowledge, TtT teachers will be expected to provide additional discipline for young people who are already marginalised.

Moreover, the introduction of TtT comes in the context of ongoing calls for more male teachers. The argument goes that men will be able to provide the discipline needed to contain disruptive and under-achieving young (mostly) males (Read 2008). However, as mentioned above, there seems to be some confusion between men and masculinity, as some ex-army will, of course, be women. Also, there is no evidence to suggest that male teachers do provide 'better' discipline. However, important here is that the call for (male? masculine?) service-leavers devalues the work being done by a predominantly female teaching staff currently in UK schools.

The second key implication is that TtT seems to render ITE in general virtually irrelevant. There is an assumption that ex-armed forces will somehow automatically maintain discipline in the classroom (Dermott 2011,9), assumed to be an inevitable consequence of them having been in the army. The Centre for Policy Studies Report generalises, arguably somewhat naively, '[e]x-servicemen are sure of their own moral authority and are not intimidated' (Burkard 2008,5). There is a lack of acknowledgement that, unlike schools with their diverse cohorts of young people and compulsory attendance, '[the Army] is a community with shared values, which respects its leader as an embodiment of those values. The reason Army officers are respected is because everyone they command is - voluntarily a member of the military community with a very strong shared identity and purpose' (Wright 2011) - there is therefore every reason to believe that some young people will resist and cause discipline problems, as with every other teacher. Equally, there is no acknowledgement of the 
different type of discipline required in schools from that required in the army. As Gilbert (2009) argues,

The army is very different from school; soldiers have to be trained to deal with life or death situations. Disobedience has to be stamped upon immediately with the most severe punishments. Discussion or questioning of orders is largely forbidden because it has to be; no soldier in the context of battle can start ruminating about the validity of a superior's orders.

There is also no acknowledgement at all of the harassment, bullying, abuse and racism reported as being systemic in the British army (e.g. Channel 4 2012), suggesting that ex-army can certainly not be viewed as somehow belonging to a transcendental realm of moral authority or discipline.

Moreover, TtT teachers will not be expected to be subject specialists, further rendering ITE irrelevant for this cohort. Despite one of the main aims of the TtT programme explicitly being improving educational achievement, there is little mention of teaching and learning in the literature (Dermott 2011,9). The White Paper cites the most recent OECD PISA survey, carried out in 2006, in which England 'fell from 4th in the world in the 2000 survey to 14th in science, 7 th to 17th in literacy, and 8th to 24th in mathematics' (Cameron and Clegg 2010,3). However, the focus in the White Paper remains around behaviour and discipline. Although the British army places much emphasis on subject skill knowledge and technical competence, skills such as engineering, medicine and cookery are not mentioned in communications about the value of ex-service personnel to schools (Dermott 2011). This, along with the claim that TtT teachers will not necessarily be expected to have a degree, contrasts with the government's professed determination to make teaching into an elite profession. Evidence suggests that very few ex-army members have a first degree in the UK, a much lower level than in the US (Dermott 2011).

It merits attention that these moves all come in the wider context of the devaluing of teacher education in general. The same White Paper (2010) calls for more training to take place in teaching schools, rather than in universities, despite student teachers already spending large chunks of the PGCE ${ }^{\mathrm{ii}}$ in schools. TtT is one of many new routes into teaching, including widening of school based routes, Teach First, Teach Next (for those wanting a change of career), which take teacher education out of universities, decreasing the opportunities for student teachers to engage with different theoretical and critical approaches. As Maguire (2011) argues, such constructions position teaching as a skill which can simply be acquired, with a focus on prescribed methods, suggesting "the teacher is reconstructed as a state technician" (p32).

\section{The military-industrial-education complex}

There is, I argue, a wider and more sinister political context to the TtT initiative. Western societies, particularly urban areas, are becoming ever-more militarized and securitized spaces. This can be observed in developments such as militarized policing at demonstrations and public events, the extent of surveillance cameras in both private and public spaces, military-style borders around areas such as financial districts, embassies and airports, the introduction of biometric surveillance, the explosion of gated communities. As Giroux (2011) argues, '[h]igh-intensity policing is no longer merely a tactic or policy, it has become a mode of governance' (p. viii). These are techniques of security and surveillance commonly associated with war-torn regions such as Baghdad and Gaza, and the massive cities of the global south (Graham 2011). However, they are now widely employed in western cities. 
The process of militarisation is commonly associated with the so-called 'war on terror' which has formed the response to the attacks of $11^{\text {th }}$ September 2001 on the US. However, it began before 2001, and set the stage for the militarised response to those attacks. Now it has been argued that the ensuing 'war on terror' is perpetual and all-pervasive (Butler 2004; Graham 2011), impacting on populations in the US and Europe as well as Afghanistan and Iraq.

This militarisation should be understood in relation to the global expansion of markets (Graham 2011; Saltman 2011). This involves both the marketisation of all aspects of life in the west, as well as globally. In order to ensure the global triumph of capitalism and marketisation, populations have to be forced to accept the values and policies of neoliberalism. This involves the removal of constraints on business and the imposition of constraints on the population. As I argue elsewhere (Chadderton 2013) this combination of market liberalisation and security, summarised by Gamble (1994) as the politics of 'the free economy and the strong state', has been a key element of 'New Right' thinking in the US and UK since the 1970s, and exemplified by the Reagan and Thatcher governments in the 1980s. The focus of state spending is shifting away from care and towards control (Harvey 2003), that is, away from social welfare, and towards the surveillance and control of populations. The public sphere is redefined as a profit opportunity and citizens redefined as consumers. One of the main implications of this redefinition of the public sphere and citizenship is the criminalization of disadvantage. Those who are economically inactive are positioned as threatening to the neoliberal project, referred to as 'flawed consumers' (Bauman 1998). Large groups of people are being created for whom neither much work nor social support is available, referred to as 'disposable' (Giroux 2009). These disadvantaged groups are therefore positioned as requiring discipline and containment.

As the government withdraws its support for the welfare of the population and turns increasingly to profit and away from democratic practice, it makes sense that it will need ever more repressive apparatuses to ensure the compliance of the population and prevent revolt. Those most likely to revolt are the disadvantaged or 'disposable' youth, as seen in the UK's 2011 riots, and frequent protests in the French banlieues. It should come as no surprise that those in power combine traditional RSAs and ISAs: schools and the army, to help achieve this.

\section{'The Home Front': Securitisation, children and schools}

[C]ontemporary war takes place in supermarkets, tower blocks, subway tunnels, and industrial districts rather than open fields, jungles or deserts (Graham 2011, xiv)

The culture of securitization and war is shaping everyday life, including school and educational cultures and discourses. One of the main functions of incipient militarisation is to increase acceptance among the population for permanent war (Graham 2011). As Althusser (1971) would argue, there is a need to ensure that the population is conditioned to accept the ideology of the ruling class, which, in this case, involves imposing neo-liberal values on the world through violence and war. Schulze von Glasser (2012) has referred to military engagement in German schools as 'The Home Front'. The impact of the militarisation culture on education and children's lives is vast. Schools in the US have been compared to maximum security prisons (Hope 2009), with features including on-site police officers, mandatory drug testing, CCTV cameras even in toilets, metal detectors and biometric testing (Giroux 2011; Monahan and Torres 2010). Schools in the UK, whilst not (yet) so securitized as those in the US, have also already introduced many of these measures (see Chadderton 2012b). Schools in both the US and UK are criminalizing the young for relatively minor infractions which 
would previously have been dealt with by the headteacher, parents and governors (Giroux 2011).

The boundaries are blurring between children's toys and real weapons. As Graham (2011) argues, toys have always mimicked weapons, but now weapons are starting to mimic toys, e.g. some military weapons mimic PlayStation controls. Whilst I do not argue that young people cannot tell the difference between simulation and reality on the one hand, on the other, these are 'hyperreal constructions [...] through which war and violence are constructed, legitimized and performed' (Graham 2011,22).

TtT can be seen, to some extent, as contributing to this militarisation and the conditioning of the population to accept a culture of permanent war. The incipient militarisation makes war seem natural, and normalizes and glorifies violence. German evidence suggests that military programmes in schools teach young people to regard war as something positive, a legitimate and logical response to which there is no alternative (Schulze von Glasser 2012). Children and adults are educated 'to identify with militaristic, authoritarian and anti-democratic practices' (Saltman and Gabbard 2011, 19). Education joins the cultural pedagogies of mass media which support identification with the military, violence, social inequality and consumerism (Saltman and Gabbard 2011, 22), rendering such values common sense. Saltman (2011) argues that programmes such as TtT turn 'hierarchical organization, competition, group cohesion, and weaponry into fun and games' (p.1), thus rendering these values more acceptable to the population. There has been criticism of the German army's project days in schools, which focus disproportionately on the role of the army as 'peacekeepers' and 'conflict resolution' in order to attract ideological support for Germany's wars, and silence discussion of alternatives to military conflict, Germany's geopolitical interests, and the realities of violent conflict for both victims and soldiers (Schulze von Glasser 2012).

A further function of the militarisation of schools is potentially military recruitment. In the US, there is evidence that the TtT programme is linked to military recruitment (Saltman and Gabbard 2011). Whilst there are no precise figures available for military recruitment linked to TtT, a similar programme, Junior Reserve Officers Training Corps (JROTC), which also sends ex-military servicepeople into schools, is seen as a recruitment programme (Brown 2011). This programme also targets poor, inner city areas, mostly African American and Latino communities, with high rates of joblessness, marketed as " "a way out" for poor youth of color' (p. 138). As Eugene J. Carroll, deputy director for the Center for Defense Information stated, '[i]t is appalling that the Pentagon is selling a military training programme as a remedy for intractable social and economic problems in inner cities. Surely, its real motive is to inculcate a positive attitude towards military service at a very early age, thus creating a storehouse of potential recruits' (Carroll, cited in Brown 2011, 140). In Germany, there is a direct connection with recruitment, engagement between the military and secondary schools having increased greatly since the abolition of compulsory military service (Schulze von Glasser 2012). Although it could be argued that the military is actually currently being downsized in the West, and such conditioning of the population is therefore not necessary, one could also assert that the West is fighting wars on many fronts, and even where war has not officially been declared, there is military activity, such as the operation of drones in Pakistan. In order to continue to spread neo-liberal values, the West needs the ideological support of the population for military action.

It is not the first time that education has been tied to militarisation, it was for example during the Cold War, but the connection between militarisation and the marketisation of education is new (Saltman 2011) and thus the direct connection with the current increase in social inequalities caused by neoliberal policies. The more recent securitisation of schools, 
then, needs to be viewed in the neoliberal context of high-stakes testing, league tables which rank schools according to narrow markers of pupil success in exams, the introduction of market values in schooling e.g. Free Schools in the UK. All these changes in education have been sold to the population by employing a rhetoric of increased choice and improved standards, but all have been shown to increase social inequalities (Ball 2007). It is this connection with increased social inequalities to which I move next.

\section{Race, militarisation and schools}

The militarisation of society is a racial issue. Firstly, as many theorists have argued, the wars of the west are imperial, racist wars (Graham 2011; Harvey 2003; Saltman 2011). Imperial discourses dominate as the west seeks to justify the ongoing 'war on terror' with populations at home. Such discourses depend on the dehumanisation of the racial 'other'- the dehumanisation is not new, but is reinforced by the 'war on terror' (Graham 2011; Butler 2004). Equally, military nationalism tends to have white supremacist overtones, to be linked to notions of racial homogeneity and cultural superiority (Hall 2011; Preston 2007). Military programmes in schools, then, provide preparation for racial domination abroad (Brown 2011), in terms of both soldier recruitment, and on an ideological level. An example of lesson material recently used by the military in German schools included a page entitled 'Threats of the $21^{\text {st }}$ century', with pictures of Iranian president Mahmoud Ahmadinejad and a full boat of North African refugees off the coast of Spain (Schulze von Glasser 2012, 75). It could be argued that the implication of such pictures is to locate the perceived threat beyond the borders of German/European whiteness, both physically and racially, and to feed white supremacist nationalism. As I argue above, this may well be in the form of tacit intentionality (Gillborn 2005).

Secondly, such white supremacist wars also shape racial realities at home. Critical Race Theorists (Ladson-Billings 2003; Oztas 2011) have examined the role of the current 'war on terror' in shaping racial discourses, arguing that identities have become polarised into those who are with the US and the UK, and those who are against. The population is perceived as divided: one group which is to be protected from threat - those categorised as white -, and a group which is threatening - the racial other. In this case the alleged terrorists are Muslims, pre-defined as belonging to an uncivilised culture, incompatible with the values of the west. This is of course not new, but builds on longstanding orientalist discourses of Islam as an under developed culture which condones, even encourages violence.

the way in which urban life in colonised zones is imagined reverberates powerfully in the cities of the colonisers. Indeed, the projection of colonial tropes and security exemplars into postcolonial metropoles in capitalist heartlands is fuelled by a new 'inner city Orientalism' (Graham 2011, xix)

Such discourses shape racial reality in western cities. In the UK, the right wing have long portrayed multi-ethnic urban areas as unBritish, external to the nation, and threatening to a white, monocultural suburban or rural nation with (partially imagined) traditional values (Chadderton 2009). Similarly in France, immigrant districts are portrayed as backward and threatening to the cities, a discourse employed to justify the aggressive policing of the riots in 2005. Graham (2011) argues that this process is shaped by the memory of the anti-colonial wars in north Africa. A similar situation prevails in the US, where the discourse dominates that urban areas are dominated by minority ethnic communities who allegedly do not share white values. It has been argued that the portrayal of African American youth in mainstream US media is very similar to the portrayal of the terrorists who threaten America (Graham 
2011, 45). The racial 'other' is thus positioned as a threat, requiring containment and pacification, this portrayal justifying increased surveillance and policing.

Very much linked to this point, the culture of securitization is also resulting in changing notions of citizenship: rather than being regarded as civilians with universal citizenship, citizens are separated into two distinct groups: potential citizens and potential targets. As Graham (2011) argues, they are separated based on the profiling of individuals, groups, communities, places, behaviours, and perceived association with factors such as violence, crime, resistance to dominant neoliberal capitalism, places. This profiling tends to be racial, those who tend to be understood as non-citizens are racial others (Butler 2004), which strengthens white privilege.

Thirdly, a culture of securitization 'legitimates a biopolitics of punishment and disposability' (Giroux 2011, viii). As I argue above, rather than providing employment or welfare support for young people from disadvantaged backgrounds, neoliberal governments invest in policing and surveillance of these groups perceived as 'disposable'. Those classified as 'disposable' tend to be already marginalized along lines of race and class. The militarisation of schools can be seen as part of a number of policies which criminalise youth, particularly minority ethnic and disadvantaged young people (Lipman 2011) and therefore feed white supremacy. In being classified as in need of the army for discipline, this in turn further confirms the racist stereotype that such groups are undisciplined, violent, tending to anti-social or criminal behaviour, and threatening to the social order, contributing to the essentialisation and fixing of such racial categories.

Indeed, it could be argued that high security, militarized schooling contributes to preparing disadvantaged young people, for whom there is little or no paid work once they leave school, for a life in jail by conditioning them to accept such an environment. The US has the highest prison population in the world, with one in 100 Americans incarcerated (Alexander 2010). At present, the UK incarcerates more young people than any other EU country (BBC 2009), and the number of children held in prison on remand has risen by $41 \%$ since 2000-01 (Pemberton 2010).

Although state repression of children is not new, what is unique about the current historical moment is that the forces of domestic militarisation are expanding, making it easier to put young people in jail rather than to provide them with the education, services, and care they need to face the growing problems characteristic of a democracy under siege (Giroux 2011, xiv)

Young people of colour are disproportionately affected by the incarceration programme, to the extent that US commentators have identified what is referred to as the 'School-to-prison pipeline' for young people of colour in the US. It has recently been argued that the criminal justice system in the US can be considered 'the new Jim Crow' (Alexander 2010), 'a new process of racialised social control' (Lipman 2011, 84) through which people of colour are denied many basic rights. Black children make up $15 \%$ of young people in the US, but $46 \%$ of those incarcerated (Giroux 2011, xiv). Equally in the UK, BME people are disproportionately imprisoned: $26 \%$ of the prison population come from minority ethnic groups (Justice 2011), although only 14\% of the population is of BME heritage (Khan 2012). Like all security industries, prisons and juvenile detention centres are rapidly growing industries both in the US (Saltman and Gabbard 2011) and UK (Behindbars 2012). There is money to be made out of mass incarceration. The privatization of prisons and related facilities, referred to as the prison-industrial complex, is led by desire for higher profits (Schlosser 1998). The State Apparatus, school and the military, already function in 
connection with each other and contribute to the maintenance of capitalist relations of production. It is likely that $\mathrm{TtT}$ in the $\mathrm{UK}$ will feed into existing programmes of social control which disproportionately affect BME groups, contributing to racial disadvantage and processes of white supremacy.

Some may argue that military education programmes cannot possibly disadvantage young people of colour, because, for example, the US military is currently the largest employer of African-Americans. However, as Brown (2011) argues, despite this, 'urban military exercises predominantly target African-American urban neighbourhoods' (p.62). Viewing this through a critical race theoretical lens, I would argue, in a white supremacist culture, people of colour are also recruited to protect white privilege.

\section{Conclusion}

To return to some of the questions about race and ITE from the beginning of this paper, why does racism persist in the education system, how do structures of white supremacy function, and what does this mean for ITE? In this article I have argued that the planned TtT initiative in the UK, despite appearing to target all young people, is actually aimed at poor and racially subordinated youth. Rather than a critical education, for those subordinated along lines of class and race, a military education is to be provided - patriarchal, hierarchical and authoritarian. This is likely to further entrench the increasing polarisation in an education system which already provides two tier educational provision: $\mathrm{TtT}$ will be a programme only for the inner-city disadvantaged, whilst wealthier, whiter schools will mostly continue to get highly qualified teachers (Brown 2011). Indeed, ITE, already in the process of being devalued by wider Coalition policies, is itself further brought into question, as it seems TtT teachers will not be subject specialists, and will be expected to provide military-style discipline, the skills for which they will be expected to bring with them. By situating my consideration of $\mathrm{TtT}$ in the wider context of the militarisation of the population through education, I have argued that $\mathrm{TtT}$ could be part of a wider move to increase ideological support for foreign wars, and keep disadvantaged 'disposable' youth under surveillance both these aims ultimately in the service of neoliberal objectives. Indeed I have argued that the cooperation of an RSA and an ISA is entirely logical in order to ensure the compliance of the population in the massive social inequalities brought about the relations of capitalist production. The introduction of TtT therefore, both feeds, and is fed by white supremacy '...the processes through which whites acquire and deploy social dominance' (Levine-Rasky 2002,2), and BME young people are further disenfranchised. TtT is just one example of the ways in which white supremacy is continually upheld, and racial identities are likely to be further polarised. This is neither wholly deliberate nor wholly accidental, rather it is example of tacit intentionality.

Although schools have always been undemocratic spaces, there have equally always been moves (both by individual teachers, schools, and Local Education Authorities) to encourage more democratic participation. These recent political shifts from a system of governance towards a system of sovereignty (Butler 2004) show how the possibilities for democratic resistance and the promotion of social justice are shrinking. Racism continues to persist in the education system because the system continues to be informed by white supremacist discourses and white supremacist policies which ensure the continued dominance of white people. As I have suggested in this paper, racism should be understood less as individual acts of discrimination against BME people, rather as a system of white supremacy which ensures on every level the continued privilege of those classified as white.

What opportunities are there for resistance to the militarisation of schools? In Germany, where there is a higher level of public awareness around the issue than in the UK, 
there have been activities at schools involving teachers, students, parents and members of the community, including a small number of demonstrations outside schools, which have had varying levels of success but have always raised public awareness. At a party political level Die Linken (The Left Party) have actually petitioned parliament to prevent military involvement in schools, although their petition was rejected by all other German parties, including the Social Democrats and the Greens (Schulze von Glasser 2012).

Equally, despite the reduced spaces for resistance, writing about education as 'a site of low-intensity warfare' (Giroux 2011, xv) contributes to the possibilities for discussing these issues and raising awareness of our complicity in maintaining structures of white supremacy. Without wanting to be naive about possibilities open to teachers under present neoliberal conditions, I repeat Giroux's (1986) call for teachers to strive to become transformative intellectuals which is already a quarter of a century old, but no less relevant then than now:

transformative intellectuals [...] are not merely concerned with forms of empowerment that promote individual achievement and traditional forms of academic success. Instead, they are also concerned in their teaching with linking empowerment - the ability to think and act critically - to the concept of social transformation. [...] Acting as a transformative intellectual means helping students acquire critical knowledge about basic societal structures, such as the economy, the state, the work place, and mass culture, so that such institutions can be open to potential transformation. (p.30)

Transformative intellectuals view classrooms as spaces of dialogue, and support students to understand themselves as raced, gendered and classed subjects. Although TtT has yet to be introduced, the militarisation of education is already well underway and calls for both critical analysis of the implications for social justice and democracy, and active resistance.

\section{Acknowledgements}

This work was supported by the Economic and Social Research Council [grant reference ES/K000233/1: Mass population response to critical infrastructure collapse - a comparative approach].

Many thanks to John Preston, Rhiannon Firth and two anonymous reviewers for their comments on earlier versions of this paper.

\section{Bibliography}

Alexander, Michelle. 2010. The new Jim Crow. Mass incarceration in the age of colorblindness. New York, NY: The New Press.

Althusser, Louis. 1971. Ideology and Ideological State Apparatuses. In Lenin and Philosophy and other Essays, ed. Louis Althusser, New York: Monthly Review Press. http://www.marxists.org/reference/archive/althusser/1970/ideology.htm [Accessed 10/09/12].

Ball, Stephen J. 2007. Education PLC. Understanding private sector participation in public sector education. London, New York: Routledge.

Bauman, Zygmunt. 1998. Work, consumerism and the new poor. Philadelphia: Open University Press

BBC 2008. Retrain ex-troops as teachers. http://news.bbc.co.uk/1/hi/education/7245122.stm [Accessed 15/06/12].

BBC 2009. 'Too many' young offenders jailed. http://news.bbc.co.uk/1/hi/uk/8198496.stm [Accessed 12/01/12]. 
BBC 2011 Classroom warriors. Panorama. http://www.bbc.co.uk/programmes/b00ysnt7 [Accessed 9/06/12].

Behindbars 2012. The prison-industrial complex- privatising prisons. Roehampton University: Contemporary issues in Criminology. http://www.contemporary-issues-incriminology.com/blog/2012/03/the-prison-industrial-complex-privatising-prisons/ [Accessed 9/9/12].

Bhopal, Kalwant and John Preston. 2012. Conclusion: intersectional theories and 'race': from toolkit to 'mash-up'. In Intersectionality and 'race' in education, ed. K. Bhopal and J. Preston 213-220. New York, London: Routledge.

Blair, M. 2000. 'Race', school exclusions and human rights. In Citizenship and democracy in schools: diversity, identity, equality, ed. A. Osler. Stoke on Trent, UK and Sterling. USA: Trentham.

Broe, S. 2008. A phenomenological enquiry into the leadership experiences of troops to teachers. PhD thesis, University of Pheonix.

Brown, E. 2011. Freedom for some, discipline for 'others'. In Education as enforcement. The militarisation and corporatization of schools $\left(2^{\text {nd }}\right.$ ed.), ed. K. Saltman and D. Gabbard, 92-113. New York and London: Routledge.

Burkard, T. 2008. Troops to Teachers: A Successful Programme from America for our Inner City Schools. London: Centre for Policy Studies.

Butler, Judith. 2004. Precarious Life. The powers of mourning and violence. London and New York: Verso.

Cameron David and Nick Clegg. 2010. Foreword by the Prime Minister and Deputy Prime Minister. In Department for Education, The Importance of Teaching: The Schools White Paper 2010. London: The Stationery Office.

Chadderton, C. 2009. Discourses of Britishness, race and difference. Minority ethnic students' shifting perspectives of their school experience. $\mathrm{PhD}$ thesis, Manchester Metropolitan University.

Chadderton, C. 2012a. Problematising the role of the white researcher in social justice research. Ethnography and Education 7, no.3: 363-380.

Chadderton, C. 2012b. UK secondary schools under surveillance: the implications for race. A Critical Race and Butlerian analysis. Journal of Critical Education Policy Studies 10, no.1.

Chadderton, C. In press 2013. Secondary schools under surveillance: young people 'as' risk in the UK. An exploration of the neoliberal shift from compassion to repression. In. Technology, Society and Inequality: New Horizons and Contested Futures, ed. E. Cudworth, P. Senker and K. Walker. Peter Lang.

Channel 4. 2012. Sexual harassment and bullying rife in the army. http://www.channel4.com/news/sexual-harassment-and-bullying-rife-in-the-army. [Accessed 05/03/13]

Defense Activity for Non-Traditional Education Support (DANTES). 2011. Troops to teachers. Proud to serve again http://www.mpttt.org/Information.aspx. [Accessed 20/06/12].

Department for Education. 2010. The Importance of Teaching: The Schools White Paper 2010. London: The Stationery Office.

Department for Education. 2012. Routes into teaching http://www.education.gov.uk/get-intoteaching/troops-to-teachers/routes-into-teaching.aspx [Accessed 20/06/12].

Dermott, E. 2011. Troops to teachers: solving the problem of working class masculinity in the classroom? Critical Social Policy XX, no.X: 1-19. 
Diangelo, R. 2006. The production of whiteness in education: Asian international students in a college classroom. Teachers College Record 108, no. 10, 1983-2000.

Feistritzer, C. E., M. Hill and G. Willett. 1998. Profile of troops to teachers. Washington DC: National Center for Education Information.

Feistritzer, C. E. 2005. Profile of Troops to Teachers. Washington, DC: National Center for Education Information.

http://www.dantes.doded.mil/dantes_Web/library/docs/ttt/NCEI_TT_v3.pdf [Accessed 29/05/12].

Foucault, Michel. 1991. Discipline and punish: the birth of the prison. Trans A. Sheridan. London: Penguin.

Gamble, Andrew. 1994. The free economy and the strong state. The politics of Thatcherism, $2^{\text {nd }}$ edn. Palgrave Macmillan.

Gemini Forces 2011. Plans to bring soldiers to schools http://www.geminiforces.co.uk/News/September-2011/Plans-to-bring-Soldiers-toSchools.aspx [Accessed 25/06/12].

Gilbert, F. 2009. Soldiers in the classroom http://www.francisgilbert.co.uk/2009/06/soldiersin-the-classroom/ [Accessed 25/06/12].

Gilbert, F. 2011. The omens don't look good for Gove's Troops to Teachers programme http://www.francisgilbert.co.uk/2011/03/the-omens-don\%E2\%80\%99t-look-good-forgove\%E2\%80\%99s-troops-to-teachers-programme/ [Accessed 25/06/12].

Gillborn, D. 2005. Education policy as an act of white supremacy: whiteness, critical race theory and education reform. Journal of Education Policy 20, no. 4: 485-505.

Giroux, H. 1986. Authority, intellectuals, and the politics of practical learning. Teachers College Record 88, no.1: 22-40.

Giroux, H. 2009. Youth in a suspect society. New York and Basingstoke: Palgrave Macmillan.

Giroux, H. 2011. Foreword: governing through crime and the pedagogy of punishment. In Education as enforcement. The militarisation and corporatization of schools $\left(2^{\text {nd }} \mathrm{ed}.\right)$, ed. K. Saltman and D. Gabbard, i-xvi. New York and London: Routledge.

Gove, M. 2011. Gove speech on 'the underclass' in full. http://www.politics.co.uk/commentanalysis/2011/09/01/gove-speech-on-the-underclass-in-full

Graham, Stephen. 2011. Cities under siege. The new military urbanism. London, New York: Verso.

Hall, S. 2011. The Neoliberal revolution. Cultural Studies, 25, no.6: 705-728.

Harvey, David. 2003. The new Imperialism. Oxford: Oxford University Press.

Hope, A. 2009. CCTV, school surveillance and social control. British Educational Research Journal 35, no. 6: 891-907.

Ignatiev, N. 1997. How to be a race traitor: six ways to fight being white. In Critical white studies, ed. R. Delgado and J. Stefancic: 613. Philadelphia: Temple University Press.

Joseph, I., A. Gunter, S. Hallsworth, T. Young, F. Adenkunle. 2011. Gangs revisited: What's a gang and what's race got to do with it? London: Runnymede Trust.

Justice 2011. Race and the criminal justice system. http://www.justice.gov.uk/publications/statistics-and-data/criminal-justice/race.htm [Accessed 7/2/12]

Khan, O. 2012. Who are we? Census 2011 reports on ethnicity in the UK. http://www.runnymedetrust.org/blog/188/359/Who-are-we-Census-2011-reports-onethnicity-in-the-UK.html [Accessed 20/02/13]

Ladson-Billings, G. 2003 It's your world, I'm just trying to explain it: understanding our epistemological and methodological challenges. Qualitative Inquiry, 9, no. 1: 5-12. 
Levine-Rasky, C. 2002. Introduction. In Working through whiteness, ed. C. Levine-Rasky,125. Albany, NY: State University of New York Press.

Lipman, P. 2011. Cracking down. Chicago school policy and the regulation of black and Latino youth. In Education as enforcement. The militarisation and corporatization of schools ( $2^{\text {nd }}$ ed.), ed. K. Saltman and D. Gabbard, 73-91. New York and London: Routledge.

Maguire, M. 2011. Where next for teacher education? Research in Secondary Teacher Education 1, no. 1: 30-4.

Marnie, S. E. 2001. Troops to teachers. Program helped address teacher shortages. Report to congressional requesters. Washington DC: Report to general accounting office.

Monahan, Torin and Rodolfo D. Torres 2010. Schools under surveillance. Cultures of control in public education. New Brunswick, New Jersey, and London: Rutgers University Press

Owings, W., L. Kaplan, J. Nunnery, R. Marzano, S. Myran, D. Blackburn 2005. Supervisor Perceptions of the Quality of Troops to Teachers Program Completers and Program Completer Perceptions of their Preparation to Teach: A National Survey. Virginia Office of Troops to Teachers.

Oztas, C. 2011. The march of the Mehteran. Rethinking the human rights critiques of counter-terrorism. Utrecht Law Review 7, no. 2: 180- 191.

Pemberton, C. 2010. Youth crime down but number of children in prison too high. http://www.communitycare.co.uk/Articles/2010/05/28/114608/youth-crime-downbut-number-of-children-in-prison-too-high.htm. [Accessed 14/01/12].

Preston, John. 2007. Whiteness and Class in Education. Dordrecht: Springer.

Read, B. 2008. 'The world must stop when I'm talking': gender and power relations in primary teachers' classroom talk. British Journal of Sociology of Education 29, no. 6: 609-621.

Roopnarine, J. 2004. African American and African Caribbean fathers. In The role of the father in child development, ed. M. E. Lamb, 58-88. Hoboken, NJ: Wiley.

Saltman, K. 2011. Introduction to the first edition. In Education as enforcement. The militarisation and corporatization of schools $\left(2^{\text {nd }}\right.$ ed.), ed. K. Saltman and D. Gabbard, 1-18. New York and London: Routledge.

Saltman, K. and D. Gabbard. 2011. Introduction to the second edition. In Education as enforcement. The militarisation and corporatization of schools $\left(2^{\text {nd }}\right.$ ed. $)$, ed. K. Saltman and D. Gabbard, 19-25. New York and London: Routledge.

Schlosser, E. 1998 The prison-industrial complex. The Atlantic. http://www.theatlantic.com/magazine/archive/1998/12/the-prison-industrialcomplex/304669/ [Accessed 10/09/12].

Schulze von Glasser, Michael. 2012. Soldaten Im Klassenzimmer. Die Bundeswehr an Schulen. Cologne: PapyRossa Verlag.

Wright, M. 2011. Michael Gove, and the false allure of shiny buttons http://www.huffingtonpost.co.uk/matthew-wright/michael-gove-and-thefals_b_956229.html. [Accessed 15/06/12]. 
'Fully aware of the risks of essentialisation involved in naming, in order to offer an insight into the way these diverse groups are positioned in UK society, I use the tern BME, Black and Minority Ethnic, because this is the way in which people of colour (US terminology) are currently referred to in the UK.

ii The Postgraduate Certificate in Education is the qualification taken by those training to teach in the UK. 